power stations now being built range from 2.28 pence per $\mathrm{kWh}$ (nuclear) to 3.59 pence per $\mathrm{kWh}$ (coal). If, because of intermittent generation, windmills do not reduce the total need for installed capacity, however, the cost of wind-generated power should be compared with the costs of fuel in conventional stations, 0.61 pence per $\mathrm{kWh}$ (nuclear) and 2.30 pence per $\mathrm{kWh}$ (coal).

Hamilton Standard claims to have applied some of the principles involved in building helicopters to the design of a flexible windmill capable of bending in the wind and responding to wind coming from different directions. Until now, most windmill designs have assumed the need for a large rigid structure capable of standing up in gales and for very strong rigid sails to withstand opposing gravitational forces. Hamilton Standard is now saying that a bendy windmill can withstand considerable forces and can be built more cheaply because less material is needed.

A cheaper windmill could also operate economically in wind speeds of only $6 \mathrm{~m} \mathrm{~s}^{-1}$ to operate effectively. The ability to respond more sensitively to variations in wind direction also suggests that a flexible design of windmill might be successful in relatively low wind speeds.

In the light of these considerations, the CEGB says that it will be looking at flat inland sites, probably in the east of England, as well as hilltop sites for its first big windmills. A low inland site would have the added advantage of causing less environmental trouble than a hilltop in the rural areas of Scotland or Wales.

Judy Redfearn

\section{Nuclear generation costs compared}

The report of the Central Electricity Generating Board (CEGB) for the year to the end of March 1980 includes a detailed analysis of the costs of generating electricity from power stations of different types which is likely to be much quoted in the months ahead, when plans are being laid for the further development of the British nuclear power programme. The figures now published represent a departure from previous practice in that the assumptions on which they are based are stated more explicitly than in the past, with allowance being made for elements of cost such as the interest paid during the period of construction and the cost of decommissioning the stations concerned.

During the past year, the cost of nuclear power generated from the first generation of British "Magnox" stations was less than that of electricity from coal or oil. The costs for the past year are shown in the accompanying Table 1.

Part of the reason why the nuclear costs turn out to be so advantageous is that the initial capital costs of the Magnox stations, built between the late $1950 \mathrm{~s}$ and present-day replacement costs would be. Although the same is true of the capital costs of conventional power stations, the fact that nuclear capital costs represent a greater proportion of the total implies that the figures are not a reliable guide to the costs of building new power stations of the same types.

One surprising feature of the CEGB's operations during $1979-80$ is that the load factors of the nuclear stations were more or less the same as those of conventional stations. Electricity generated by the nuclear plant amounted to 70 per cent the late $1960 \mathrm{~s}$, are much lower than of net capacity, compared with 69 per cent for coal-fired stations and 77 per cent for oil-fired stations. Originally, it was intended that the nuclear plant in the British generating system should be run at virtually full capacity; the board says that the lower load factors now being obtained from the nuclear power stations reflect their increased age. The costs of electricity generation are obtained by dividing the total cost of operation by the amount of electricity generated and thus increase as load factors decline.

Table 2 Costs for Hinkley B (AGR) and Drax (coal-fired) Hinkley
Point B

Capital charges and provision

$$
\text { for decommissioning }
$$

$\mathrm{p} / \mathrm{kWh} \quad \mathrm{p} / \mathrm{kWh}$

Interest during construction

Inclusive fuel costs

Other costs of operation

Research

Training

Total

0.37
0.18
0.55
0.16
0.07
0.02
$\mathbf{1 . 3 5}$

0.12

$\begin{array}{ll}0.37 & 0.12 \\ 0.18 & 0.04\end{array}$

$0.55 \quad 1.25$

$0.16 \quad 0.09$

$0.07 \quad 0.01$

$0.02 \quad 0.01$

The CEGB's annual report also provides costs on a comparable basis for two of its newest power stations - the Advanced Gas-Cooled Reactor station (the first of its type to be commissioned) and the newly-completed Drax coal-fired power station. The figures are shown in Table 2. The load factors for the AGR station (Hinkley Point B) and Drax were 55 per cent and 74 per cent respectively. The poor availability of the AGR reflects the difficulties in bringing this station into operation. It may seem remarkable that, in the circumstances, the cost of electricity generated is not much greater than that from the older Magnox station.

Mainly because of inflation, the CEGB expects nuclear costs to rise. The net cost of electricity from the three AGR stations soon to be commissioned (Dungeness B, Hartlepool and Heysham I) are estimated at 2.62 pence per $\mathrm{kWh}, 2.28$ pence per $\mathrm{kWh}$ and 2.31 pence per $\mathrm{kWh}$ respectively. The increase is largely attributable to increased capital costs, three times as great as those for Hinkley Point B. At the same time, the board estimates that the cost of conventional electricity will have increased still further, with oil-fired plant producing electricity at a cost of more than 6 pence per $\mathrm{kWh}$ and the second half of the coal-fired Drax station producing electricity at 3.59 pence per $\mathrm{kWh}$.

For the first time, the CEGB also provides figures to show the basis on which future investment decisions are being made. The principle is that of discounted cash flow in which future costs are represented by a present cost using a discount rate of 5 per cent per annum. The board also makes the assumption that the price of coal will increase at an average rate of 2 per cent a year at least until the end of the century and notes that the cost of building generating plants of all

\begin{tabular}{lrr}
\hline $\begin{array}{c}\text { Table } 3 \text { Overall comparison of costs for nuclear and } \\
\text { coal-fired stations } \\
\text { Nuclear }\end{array}$ & $\begin{array}{r}\text { Coal-fired } \\
\mathrm{p} / \mathrm{kW} \mathrm{h}\end{array}$ \\
$\begin{array}{l}\mathrm{p} / \mathrm{k} \mathrm{W} \mathrm{h} \\
\text { Capital charges at station and } \\
\text { provision for decommissioning* }\end{array}$ & 1.39 & 0.76 \\
$\begin{array}{l}\text { Interest during construction* } \\
\text { Inclusive fuel costs }\end{array}$ & 0.61 & 2.38 \\
$\begin{array}{l}\text { Other costs of operation } \\
\text { Generation costs }\end{array}$ & $\underline{0.22}$ & $\underline{0.21}$ \\
$\begin{array}{l}\text { Less fuel saving from } \\
\text { displacing less efficient plant }\end{array}$ & 2.22 & $\overline{3.35}$ \\
& -0.46 & 3.02 \\
\hline
\end{tabular}

kinds has recently been increasing faster than inflation. The calculations now published, and summarized in Table 3, show that a nuclear generating plant has potential advantages over a coal-fired plant both in generating electricity more cheaply and in its effect on the economics of the generating systems as a whole assuming that nuclear plants would displace less efficient plants, the Net Effective Cost of nuclear generating capacity becomes negative, implying a net saving for each power station built.
Interest during construction

Inclusive fuel costs

Other costs of operation

Research

Training
Coal-

fired

0.09

0.02

1.29

0.14

0.01

1.56

fired
$\mathrm{p} / \mathrm{kW} \mathrm{h}$
0.14
0.02
1.61
0.14
0.01
0.01

1.93

